\title{
Modelling the Economic Impact and Ripple Effects of Disease Outbreaks
}

\author{
Krista Danielle S. $\mathrm{Yu}^{1} \cdot$ Kathleen B. Aviso ${ }^{2}$ \\ Received: 12 February 2020 / Revised: 2 March 2020 / Accepted: 4 March 2020 \\ (C) Springer Nature Singapore Pte Ltd. 2020
}

\begin{abstract}
The Coronavirus Disease 2019 (COVID-19) outbreak has had alarming effects on human lives and the economies of affected countries. With the world's manufacturing hubs experiencing a period of extended factory closures, the economic impact transcends territorial borders via global supply chains. This paper provides a roadmap on how to evaluate the vulnerability that cascades through the supply chain due to a disease outbreak at the firm level, national level, and global scale. The final extent of losses is not yet known, but the development of economic models combined with epidemiological models and network analysis techniques can yield more realistic estimates to select appropriate strategies in a timely manner.
\end{abstract}

Keywords COVID-19 $\cdot$ China $\cdot$ Economy $\cdot$ Coronavirus $\cdot$ Supply chain $\cdot$ Disease outbreak $\cdot$ Economic impact assessment

The emergence of global supply chains exposes economies to risks that go beyond their territorial borders. Beyond natural hazards and man-made disasters, the world is unprepared to handle epidemic outbreaks such as the COVID-19 outbreak. From its first reported case on December 30, 2019, the number of confirmed cases has grown at an exponential rate and continues to rise to date. As of this writing, more than 89,000 individuals have been infected (with more than 7000 cases outside of China) and more than 3000 have died. The virus has spread to more than 60 countries other than China (Dong et al. 2020). Several studies have found that the transmissibility of COVID-19 has a basic reproduction number, $R_{0}$, of 2-6.47, on average 3.58 (Liu et al. 2020), meaning the disease can spread from an average person to anywhere in between 2 and 6.47 people. This is higher than other recent disease outbreaks such as SARS, A(H1N1), Ebola, and MERS-CoV, which have $R_{0}$ values of 2-5 (World Health Organization 2003), 1.4-1.6 (Baldo et al. 2016), 1.50-2.67 (Althaus 2014), and 0.6-1.3 (MacIntyre 2014) respectively.

This article is part of the Topical Collection on COVID-19: optimization startegies to combat the pandemic.

Krista Danielle S. Yu

krista.yu@dlsu.edu.ph

1 School of Economics, De La Salle University, 2401 Taft Avenue, Malate, 0922 Manila, Philippines

2 Chemical Engineering Department, De La Salle University, Manila, Philippines
Governments around the world have issued travel restrictions, hindering foreign nationals who have been to China to enter their territories. In addition, a lockdown has been imposed in Wuhan, China, during the peak of the Chinese Lunar New Year holiday. Compared with previous years, air travel demand in China has declined by $40 \%$ by the end of January as a result of the outbreak (International Air Transport Association (IATA) 2020a). This downtrend is expected to continue in the next 6 months should previous trends prevail (IATA 2020b). The exponential growth of confirmed cases has led to China's State Council to declare an initial extension of the holiday to February 2, 2020, but later revised to February 9 for some provinces and February 13 for Hubei Province (Dezan Shira and Associates 2020). Wuhan, the epicenter of the COVID-19 outbreak, is an automobile factory hub with global brands such as General Motors, Hyundai, and Toyota (Conelly 2020). Aside from these car manufacturing plants, multinational companies such as Apple, Alphabet, Starbucks, McDonald's, and Proctor and Gamble have closed production facilities, offices, and restaurants across China (Cerullo 2020).

Most studies have focused on looking into the vulnerability of China as a result of its dependence on other countries for resources such as oil (Sun et al. 2017), changes in environmental policy to reduce emissions (Deng et al. 2016), and water scarcity issues (Wang et al. 2014). However, studies have failed to account for the possibility of experiencing labor shortages in China that can result from a disease outbreak. Such instances can impact not just local or regional activities 
but also global markets especially since China has become an economic giant.

Aside from China, travel restrictions have been imposed for countries such as Iran, Italy, South Korea, and Japan as the number of confirmed cases in these countries continues to grow (Centers for Disease Control and Prevention 2020). In Japan's Hokkaido prefecture, government went as far as asking citizens to remain indoors (Reuters 2020). These nonpharmaceutical measures lead to further losses in the hotels, restaurants, and other related sectors due to reduced number of tourists and fear of contagion. The decline in economic activity has caused share prices and commodity prices to fall. Stock markets around the world continue to suffer as the disease continues to spread. The world's 500 richest people collectively lost $\$ 444$ billion in a period of 1 week from February 21 to 28, 2020 (Metcalf et al. 2020).

Past studies have used econometric and statistical methods to estimate the economic impact of disease outbreaks. Meltzer et al. (1999) estimated the potential impact of an influenza pandemic in the USA based on the gross attack rates but without accounting for multiplier effects which can cause significant losses to the workforce. Beutels et al. (2009) employed crosscorrelation functions to compare the evolution of time series data trends to measure the economic impact of SARS in Beijing and found that there is no long-term effect since consumption spending was merely postponed. Keogh-Brown and Smith (2008) conducted a retrospective estimation using macroeconomic indicators for the affected countries and found that there was no significant impact on the economy with the exception of accommodation and restaurant sectors in Hong Kong, Australia, and Canada. Joo et al. (2019) estimated the impact of the MERS-CoV to the tourism-related sectors of the Korean economy through using a seasonal autoregressive integrated moving average model. However, these failed to capture the interdependencies across various industries within the economy.

Leontief (1936) won the Nobel Prize for developing the input-output model, which accounts for direct and indirect impacts of such disruptions on the economy. This was extended into the inoperability input-output model that yields two impact assessment measures, the degree of inoperability and economic loss which has been used to assess the impact of workforce absenteeism due to the influenza pandemic in the US National Capital Region thereby capturing the ripple effects as well as the impact of introducing interventions (El Haimar and Santos 2015). Workforce absenteeism is not only caused by the absence of workers who contracted the disease, but also workers who need to take care of sick members of the household (Santos et al. 2020). School closures may also increase workforce absenteeism as parents need to care for school-age children in the absence of childcare. In the UK, evidence showed that rate of workforce absenteeism due to school closures is $16.1 \%$, which will further amplify the shortage of health workers in times of crisis (Sadique et al. 2008)
Multi-regional analysis has been used to assess trade effects (Duan et al. 2018) and sustainability performance (Wang et al. 2020) for global supply chains; however, there is a dearth of studies that use this approach to evaluate the vulnerability that cascades through the supply chain due to disease outbreak. This can be implemented on different levels:

- At the firm level, input-output analysis can be used to illustrate the interactions between departments and teams necessary to produce in the production process. Particular examples include hospital management (Correa and Parker 2005) and business process outsourcing firm operation (Aviso et al. 2017). Optimization techniques can also be employed for efficient allocation of available resources during crisis conditions (Tan et al. 2018). P-graph network analysis (Friedler et al. 1992) may also be extended to assess multi-plant firms, which may be located in different countries, to mitigate potential losses due to plant closures.

- At the national level, there is a need to develop interregional statistical databases that will establish the interdependence of individual regions and provinces and reflect the intensity of activities taking place between regions, especially for developing economies. Developed countries typically have this database available through their various statistics agencies. Such information will allow countries to model internal impacts of possible disruptions within the system and develop risk management measures to enhance their resilience.

- At the global level, multi-regional input-output databases have been published by international agencies such as the Organisation for Economic Co-operation and Development (OECD), European Union (EU), and the Asian Development Bank (ADB) to account for interdependencies between sectors across economies. As production networks move towards a globalized direction, networks become even more complex such that effects are compounded by feedback loops which are difficult to anticipate by intuition. For example, travel restrictions result in less commercial activity and less demand for resources to support activities; labor shortage results in plant closures resulting in reduced productivity and disruptions in the supply chains. In addition, new interventions arising from apprehension due to incomplete information and uncertainty, further disrupt operations.

Economic models should be coupled with disease transmission models to include dynamics of the spread of outbreaks. Mathematical models such as the SusceptibleInfectious-Recovered (SIR) model and its extensions (Grassly and Fraser 2008) combined with mobility data yield epidemic curves that will ensure that the economic models will capture the impact of workforce absenteeism. In addition, sensitivity analysis may be implemented in accounting for the variability of recovery rate among the infected. 
The COVID-19 outbreak has proven the centrality of human resource in economic operations. It is imperative for us to develop assessment frameworks that will account for interactions across states, countries, and regions which provide timely approximations, with appropriate disclaimers on precision, for emergency decision-making. In addition, there is a need to explore other alternative approaches to assess potential risks posed by the spread of disease outbreaks and to develop risk management strategies to hedge against the impact of pandemics. These strategies include establishing more systematic protocols (Nicoll et al. 2010) and building a database of cases for disease surveillance (Gates 2020), streamlining processes for vaccination development and deployment (Jennings et al. 2008; Innis et al. 2019), putting in place emergency response plans both at the local and national levels (Chambers et al. 2012), and instituting cost-effective measures (e.g., hospital quarantines, use of anti-viral stockpiling) drawn from lessons of past experiences (Pasquini-Descomps et al. 2017). Furthermore, by utilizing current economic modelling techniques to develop optimization models which can select the most efficient and cost-effective option among available risk management strategies, and harnessing the emergence of big data and the advancements in network analysis, enhanced results can be achieved for better policymaking.

\section{Compliance with Ethical Standards}

Conflict of Interest The authors declare that they have no conflict of interest.

\section{References}

Althaus CL (2014) Estimating the reproduction number of Ebola virus (EBOV) during the 2014 outbreak in West Africa. PLOS Currents Outbreaks. https://doi.org/10.1371/currents.outbreaks. 91afb5e0f279e7f29e7056095255b288

Aviso KB, Cayamanda CD, Mayol AP, Yu KDS (2017) Optimizing human resource allocation in organizations during crisis conditions: a P-graph approach. Process Integr Optim Sustain 1:59-68. https:// doi.org/10.1007/s41660-017-0004-3

Baldo V, Bertoncello C, Cocchio S, Fonzo M, Pillon P, Buja A, Baldovin $\mathrm{T}$ (2016) The new pandemic influenza $\mathrm{A} /(\mathrm{H} 1 \mathrm{~N} 1) \mathrm{pdm} 09$ virus: it it really “new"? J Prev Med Hyg 57(1):E19-E22

Beutels P, Jia N, Zhou QY, Smith R, Cao WC, De Vlas SJ (2009) The economic impact of SARS in Beijing, China. Tropical Med Int Health 14:85-91

Centers for Disease Control and Prevention (2020) Coronavirus disease 2019 information for travel. https://wwwcdcgov/coronavirus/2019ncov/travelers/indexhtml. Accessed 02 March 2020

Cerullo M (2020) China coronavirus causing chaos for U.S. companies. https://www.cbsnews.com/news/coronavirus-brings-businessoperations-in-china-to-standstill/. Accessed 10 February 2020

Chambers J, Barker K, Rouse A (2012) Reflections on the UK's approach to the 2009 swine flu pandemic: conflicts between national government and the local management of the public health response. Health \& Place 18(4):737-745
Conelly F (2020) China virus roils supply chains for global manufacturers. https://wwwbloombergcom/news/articles/2020-02-07/chinavirus-crisis-roils-supply-chains-for-global-manufacturers. Accessed 10 February 2020

Correa H, Parker BR (2005) An application of organizational inputoutput analysis to hospital management. Socio Econ Plan Sci 39(4):307-333

Deng G, Ding Y, Ren S (2016) The study on the air pollutants embodied in goods for consumption and trade in China - accounting and structural decomposition analysis. J Clean Prod 135:332-341

Dezan Shira \& Associates (2020) China extends Lunar New Year holiday to February 2, Shanghai to February $9 \mathrm{https}$ ://wwwchinabriefingcom/news/china-extends-lunar-new-year-holiday-february2-shanghai-february-9-contain-coronavirus-outbreak/. Accessed 07 February 2020

Dong E, Du H, Gardner L (2020) An interactive web-based dashboard to track COVID-19 in real time. Lancet Infect Dis; published online Feb 19 2020. 10.1016/S1473-3099(20)30120-1

Duan Y, Dietzenbacher E, Jiang X, Chen X, Yang C (2018) Why has China's vertical specialization declined? Econ Syst Res 30(2):178-200

El Haimar A, Santos JR (2015) A stochastic recovery model of influenza pandemic effects on interdependent workforce systems. Nat Hazards 77:987-1011

Friedler F, Tarjan K, Huang YW, Fan LT (1992) Graph-theoretic approach to process synthesis: axioms and theorems. Chem Eng Sci 47(8):1973-1988

Gates B (2020) Responding to Covid-19 - a once in-a-century pandemic? N Engl J Med. https://doi.org/10.1056/NEJMp2003762

Grassly N, Fraser C (2008) Mathematical models of infectious disease transmission. Nat Rev Microbiol 6:477-487. https://doi.org/10. 1038/nrmicro1845

Innis BL, Scorza FB, Blum JS, Jain VK, Aguilar AO, Post DJ, Roberts PC, Wairagkar N, White J, Bresee J (2019) Meeting report: convening on the influenza human viral challenge model for universal influenza vaccines, part 1: value; challenge virus selection; regulatory, industry and ethical considerations; increasing standardization, access and capacity. Vaccine 37(35):4823-4829

IATA (2020a) The impact of the novel coronavirus on air travel demand. IATA Economics' Chart of the Week. https://www.iata.org/en/iatarepository/publications/economic-reports/cotw-feb-7th-2020/. Accessed 10 February 2020

IATA (2020b) What can we learn from past pandemic episodes? IATA Economics' Chart of the Week. https:/www.iata.org/en/iatarepository/publications/economic-reports/what-can-we-learn-frompast-pandemic-episodes/. Accessed 10 February 2020

Jennings LC, Monto AS, Chan PK, Szucs TD, Nicholson KG (2008) Stockpiling prepandemic influenza vaccines: a new cornerstone of pandemic preparedness plans. Lancet Infect Dis 8(10):650-658

Joo H, Maskery BA, Berro AD, Rotz LD, Lee YK, Brown CM (2019) Economic impact of the 2015 MERS outbreak on the Republic of Korea's tourism related industries. Health Security 17(2):100-108

Keogh-Brown MR, Smith RD (2008) The economic impact of SARS: How does reality match the predictions. Health Policy 88:110-120

Leontief W (1936) Quantitative input and output relations in the economic system of the United States. Rev Econ Stat 18:105-125

Liu Y, Gayle AA, Wilder-Smith A, Rocklöv J (2020) The reproductive number of COVID-19 is higher compared to SARS coronavirus. J Travel Med. https://doi.org/10.1093/jtm/taaa021

MacIntyre CR (2014) The discrepant epidemiology of Middle East respiratory syndrome coronavirus (MERS-CoV). Environ Syst Decis 34: 383-390. https://doi.org/10.1007/s10669-014-9506-5

Meltzer MI, Cox NJ, Fukuda K (1999) The economic impact of pandemic influenza in the United States: priorities for intervention. Emerging Infecti Dis 5(5):659-671

Metcalf T, Witzig J, Maloney T (2020) World's richest lose \$444 billion after hellish week for markets. https://wwwbloombergcom/news/ 
articles/2020-02-28/world-s-richest-lose-444-billion-after-hellishweek-for-markets. Accessed 02 March 2020

Nicoll A, Ammon A, Amato A, Ciancio B, Zucs P, Devaux I, Plata F, Mazick A, Molbak K, Asikainen T, Kramarz P (2010) Experience and lessons from surveillance and studies of the 2009 pandemic in Europe. Public Health 124(1):14-23

Pasquini-Descomps H, Brender N, Maradan D (2017) Value for money in H1N1 influenza: a systematic review of the cost-effectiveness of pandemic interventions. Value Health 20(6):819-827

Reuters (2020). Japan's Hokkaido prefecture declares state of emergency over coronavirus. https://wwwnytimescom/reuters/2020/02/28/ world/asia/28reuters-china-health-japan-hokkaidohtml. Accessed 01 March 2020

Sadique MZ, Adams EJ, Edmunds WJ (2008) Estimating the costs of school closure for mitigating an influenza pandemic. BMC Public Health 8:135. https://doi.org/10.1186/1471-2458-8-135

Santos J, Yip C, Thekdi S, Pagsuyoin S (2020) Workforce/Population, Economy, Infrastructure, Geography, Hierarchy, and Time (WEIGHT): reflections on the plural dimensions of disaster resilience. Risk Anal 40(1):43-67
Sun X, Liu C, Chen X, Li J (2017) Modeling systemic risk of crude oil imports: case of China's global oil supply chain. Energy 121:449-465

Tan RR, Aviso KB, Promentilla MAB, Yu KDS, Santos JR (2018) Inputoutput models for sustainable industrial systems. Springer Nature, Singapore

Wang W, Gao L, Liu P, Hailu A (2014) Relationship between regional economic sectors and water use in a water-scarce area in China: a quantitative analysis. J Hydrol 515:180-190

Wang Q, Song X, Liu Y (2020) China's coal consumption in a globalizing world: Insights from multi-regional input-output and structural decomposition analysis. Sci Total Environ 711:134790

World Health Organization (2003) Consensus document on the epidemiology of severe acute respiratory syndrome (SARS). WHO/CDS/ CSR/GAR/2003.11

Publisher's Note Springer Nature remains neutral with regard to jurisdictional claims in published maps and institutional affiliations. 